\title{
TERAPI ALQURAN MEMINIMALKAN RISIKO DEPRESI IBU HAMIL DENGAN FETAL ANOMALY: PENERAPAN EVIDENCE BASED PRACTICE
}

\author{
Vella Yovinna Tobing ${ }^{1}$, Yati Afiyanti ${ }^{2}$, Tri Budiati ${ }^{3}$ \\ ${ }^{1}$ Program Studi Ilmu Keperawatan STIKes Hang Tuah Pekanbaru \\ ${ }^{2,3}$ Departemen Keperawatan Maternitas, Fakultas Ilmu Keperawatan Universitas Indonesia \\ email: vellayovito@gmail.com
}

\begin{abstract}
Abstrak
Kehamilan dengan fetal anomaly menimbulkan distres pada orang tua, terlebih jika kehamilan tersebut merupakan kehamilan yang sangat diharapkan dan sudah direncanakan. Stres yang dirasakan karena adanya pengalaman tidak menyenangkan berupa kehilangan dapat memberikan dampak berupa trauma pada kehamilan berikutnya. Studi kasus ini dilakukan pada dua pasien yang didiagnosa mengalami fetal anomaly pada kehamilannya yang berlokasi di salah satu rumah sakit rujukan Nasional. Studi kasus ini dilakukan dengan mengaplikasikan evidence based practice (EBP) yang dilakukan dari masa kehamilan sampai dengan masa postpartum. Umumnya, ibu dan keluarga merasakan kesedihan, kecemasan, membutuhkan informasi terkait kelainan dan juga dilema dalam membuat keputusan terkait terminasi kehamilan. Salah satu intervensi keperawatan yang dapat dilakukan untuk meminimalisir dampak kehilangan yaitu dengan melakukan pendekatan spiritual. Metode pelaksanaan EBP terkait pendekatan spiritual pada studi ini adalah dengan mendengarkan bacaan Alquran. Edinburgh Postnatal Depression Scale digunakan sebagai alat ukur untuk menilai risiko depresi, dengan pertimbangan skala ini berisi pertanyaan yang sedikit dan mudah untuk dianalisis. Hasil penerapan EBP, terdapat perubahan nilai skala depresi menuju kearah positif, sehingga mendengarkan bacaan Alquran dapat dijadikan salah satu intervensi bagi perempuan yang didiagnosis mengalami kehamilan dengan fetal anomaly untuk meminimalisir risiko depresi.
\end{abstract}

Kata Kunci: depresi, fetal anomaly, kehilangan, mendengarkan Alquran

\begin{abstract}
Fetal anomaly pregnancy causes parents' distress, especially if the pregnancy is an expected and planned pregnancy. The perceived stress of having an unpleasant experience of loss can have traumatic effects on subsequent pregnancies. This case study was performed on patients who diagnosed with anomaly fetal pregnancy which located in national referral hospital in Indonesia. Evidence based practice was applicated during perinatal period in this study. Generally, mothers and families feel sadness, anxiety, need information related abnormalities and also a dilemma in making decisions related to the termination of pregnancy. One of the nursing interventions that can be done to minimize the impact of loss is by doing a spiritual approach, one of them by listening to the recitation of the Qur'an, this method was used as an intervention in this study. The Edinburgh Postnatal Depression Scale is used as a measuring tool for assessing the risk of depression, with consideration of this scale of questions that are few and easy to analyze. The result of EBP application showed that there is a change in the value of the depression scale towards the positive, so listening to the Qur'an reading can be one of intervention for women who are diagnosed with pregnancy with fetal anomaly to minimize the risk of depression.
\end{abstract}

Keywords: depression, fetal anomaly pregnancy, loss, hearing Quran

\section{LATAR BELAKANG}

Kelainan kongenital menyebabkan

kecatatan yang memiliki efek jangka panjang

baik pada individu, keluarga, sistem pelayanan

kesehatan dan masyarakat (WHO, 2016).
Adanya kelainan kongenital dapat dideteksi secara dini sejak masa kehamilan. Terdapat beberapa metode skrining yang bisa dilakukan, baik bersifat non invasif maupun invasif. USG adalah metode non invasif yang dapat 
Vella Yovinna Tobing1, Yati Afiyanti², Tri Budiati3, Terapi Alquran Meminimalkan Risiko Depresi Ibu Hamil Dengan Fetal Anomaly: Penerapan Evidence Based Practice

mendeteksi adanya kelainan kongenital pada janin. Deteksi dini melalui USG sudah efektif dilakukan pada usia gestasi 12-13 minggu (Kenkhuis et al., 2018). Pemeriksaan USG yang dilakukan pada trimester pertama kehamilan mampu mengidentifikasi sekitar $50 \%$ defek struktural (Kashyap, Pradhan, Singh, \& Yadav, 2015).

Penyebab dan faktor risiko terjadinya kelainan kongenital tidak bisa dihubungkan langsung dengan penyebab spesifik. Faktor genetik, faktor sosial-ekonomi dan demografi, faktor lingkungan, infeksi dan juga status nutrisi maternal merupakan faktor risiko yang dapat menyebabkan terjadinya kelainan kongenital (WHO, 2016). Terpapar pada polusi udara dan polusi suara selama masa kehamilan dapat meningkatkan risiko terjadinya kelainan kongenital (Pederson et al, 2017).

Tindakan pencegahan yang bisa dilakukan untuk meminimalisir risiko terjadinya kelainan kongenital diantaranya memastikan keadekuatan intake nutrisi pada perempuan disepanjang siklus reproduksinya, menghindari zat-zat yang membahayakan (seperti alkohol, pestisida), kontrol penyakit kronis (diabetes mellitus, hipertensi), pemberian vaksinasi, skrining infeksi dan meningkatkan cakupan edukasi kesehatan terkait kelainan kongenital. Intake nutrisi yang adekuat dapat meningkatkan kesejahteraan janin. Nutrisi memiliki peranan penting dalam pertumbuhan dan perkembangan janin, dan periode emas pemenuhan nutrisi adalah seribu hari pertama kehidupan (Black et al, 2013). Intake asam folat yang adekuat selama masa prenatal terbukti dapat menurunkan kejadian defek tuba-neural dan defek jantung bawaan (Czeizel, Dudás, Vereczkey, \& Bánhidy, 2013).

Selain meningkatkan morbiditas dan mortalitas pada neonatus dan balita, kehamilan dengan kelainan kongenital juga menimbulkan efek tersendiri pada ibu dan keluarga. Keputusan terminasi kehamilan seringkali membuat orang tua tertekan dan merasa bersalah terhadap keputusan dan konsekuensi yang telah diambil untuk mengakhir kehamilan (Hunt, France, Ziebland, Field, \& Wyke, 2009). Pengalaman terkait kegagalan pada kehamilan akan memberikan pengaruh pada kehamilan berikutnya, dimana masih ditemukan konflik emosional, kecemasan yang berlebihan, isolasi dan kurangnya keyakinan akan luaran yang baik (Mills et al., 2014). Pengalaman komplikasi kehamilan yang dirasakan baik oleh ibu maupun keluarga diantaranya adalah ketidakyakinan, kebutuhan akan informasi, stres dan kecemasan, penantian, dilema dalam membuat keputusan, isolasi, rasa kehilangan dan kesedihan, adanya berbagai kemungkinan sampai pada proses penerimaan dan adaptasi (Tucker, 2016).

\section{METODOLOGI PENELITIAN}

Ini merupakan studi kasus yang dilakukan di salah satu rumah sakit rujukan nasional di Indonesia. Studi kasus ini dilakukan pada dua orang pasien yang menjadi 
responden dalam studi ini. Studi ini dimulai dari masa prenatal sampai dengan masa postnatal. Pada studi ini dilakukan penerapan evidence based practice pada responden, yaitu dengan mendengarkan murottal Alquran sebagai intervensi yang dipilih untuk menurunkan risiko terjadinya depresi. Bacaan Alquran yang diperdengarkan adalah bacaan surat Ar-Rahman oleh Shyaykh Mishari Alafasy. Responden dianjurkan mendengarkan sekali dalam satu hari.

Penilaian EPDS diberikan saat pertama kali bertemu dengan pasien. Lalu pasien diberikan penjelasan terkait manfaat mendengarkan dan membaca Al-Quran. Kedua pasien merasa tertarik dan mengatakan akan mencoba rutin untuk membaca Al-Quran setiap hari.

Saat pasien di rawat di rumah sakit pasca tindakan persalinan, dilakukan pengkajian terkait pelaksanaan terapi mendengarkan bacaan Al-Quran. Sebelum pulang ke rumah pasca perawatan post SC, pasien diberikan kembali form EPDS untuk mengetahui risiko depresi pada pasien.

Pasien yang datang dengan diagnosis kelainan kongenital pada janin diberikan anjuran untuk mendengarkan bacaan Alquran. Pasien juga diberikan kuesioner EPDS untuk mengetahui risiko depresi pada pasien. Rekaman bacaan Alquran diberikan pada pasien melalui transfer data dari telepon seluler. Bacaan Alquran yang diperdengarkan adalah bacaan surat Ar-Rahman oleh Shyaykh
Mishari Alafasy. Pasien dianjurkan mendengarkan sekali dalam satu hari.

\section{Case Hystory}

Kasus pertama, Ny. I, 29 tahun, G1H 3435 minggu, didiagnosis mengalami multiple anomaly congenital berupa Tetralogy of Fallot, atresia duodenum dan hypoplasia nasal. Kelainan kongenital yang dialami bukanlah kondisi letal, sehingga kehamilan masih dipertahankan. Hasil pemeriksaan anti IgG CMV dan IgG Rubella positif, namun tidak memengaruhi tatalaksana kehamilan saat ini. Pasien juga didiagnosa memiliki kista dermoid dengan ukuran $15 \mathrm{~mm}$ pada bagian kanan dan $55 \mathrm{~mm}$ pada bagian kiri. Ukuran janin cenderung kecil bila dibandingkan dengan usia janin, akan dikontrol setiap dua minggu. Hasil pemeriksaan tanda-tanda vital, tekanan darah: 164/98 mmHg, nadi: $103 \mathrm{kali} / \mathrm{menit}$, pernapasan: $20 \mathrm{kali} / \mathrm{menit}$ dan suhu: $36.5^{\circ} \mathrm{C}$. Keluhan yang dirasakan oleh pasien adalah merasa kaku pada sendi jari-jari tangan terutama saat pagi hari, kaki terasa semakin membesar, namun tidak merasakan adanya nyeri kepala atau keluhan pandangan yang kabur. Hasil pengukuran ulang tekanan darah: 170/110 mmHg hasil dipstick urin: proteinuria +2. Tafsiran berat janin 1400 gram, janin cenderung kecil. Pasien diputuskan untuk rawat di ruangan untuk tatalaksana preeklampsia dan pematangan paru selama dua hari. Pasien juga direncanakan untuk melakukan terminasi kehamilan pasca pematangan paru. Pasien dan keluarga merasa 
Vella Yovinna Tobing1, Yati Afiyanti², Tri Budiati3, Terapi Alquran Meminimalkan Risiko Depresi Ibu Hamil Dengan Fetal Anomaly: Penerapan Evidence Based Practice

sangat cemas dengan kondisinya saat ini, apalagi saat diminta rawat inap.

Kasus kedua, Ny. H, 30 tahun, G2P1A0H 36-37 minggu, rujukan dari RSUD Koja dengan diagnosa suspect Hydrocephalus. Antenatal Care teratur. Pengukuran tandatanda vital, tekanan darah: 110/70 $\mathrm{mmHg}$, nadi: $83 \mathrm{kali} / \mathrm{menit}$, pernapasan: $22 \mathrm{kali} / \mathrm{menit}$ dan suhu: $36.7^{0}$ C. Kondisi umum pasien baik, namun pasien dan suami terlihat sangat cemas saat dilakukan pemeriksaan. Hasil USG Fetomaternal terdapat pelebaran ventrikel anterior dan posterior di kepala yang mengindikasi hydrocephalus, jenis kelamin laki-laki, tali pusat terdiri dai satu vena dan dua arteri dan terdapat tanda hiperfusi pada janin. Kehamilan ini merupakan kehamilan yang direncanakan dan sangat diinginkan oleh pasien dan suaminya. Pasien direncanakan untuk melakukan terminasi kehamilan jika kehamilan sudah dinyatakan aterm.

\section{HASIL IMPLEMENTASI}

Perbedaan implementasi pada kedua kasus terletak pada lama penerapan intervensi. Pasien mulai mendengarkan bacaan Alquran sejak hari pertama pasien setuju untuk menerapkan evidenced based practice. Penerapan dilakukan sampai pasien selesai dirawat pasca melakukan terminasi kehamilan. Pada kasus pertama, intervensi dilakukan selama enam hari, sedangkan pada kasus kedua, intervensi dilakukan selama 14 hari.
Tabel 1.

Hasil penilaian EPDS saat hamil dan setelah melahirkan

\begin{tabular}{lcc}
\hline Inisial & $\begin{array}{c}\text { Skor } \\
\text { Pengukuran } \\
\text { I (prenatal) }\end{array}$ & $\begin{array}{c}\text { Skor } \\
\text { Pengukuran } \\
\text { II } \\
\text { (postnatal) }\end{array}$ \\
\hline Ny. I & 12 & 7 \\
Ny. H & 11 & 9 \\
\hline
\end{tabular}

Hasil pengukuran EPDS menunjukkan bahwa terjadi penurunan risiko depresi pada kedua pasien, meskipun terdapat perbedaan lama mendengarkan Alquran. Pasien pada kedua kasus awalnya memiliki risiko sedang untuk terjadinya depresi. Terjadinya perubahan yang positif pada kedua pasien pasca mendengarkan bacaan Al-Quran secara rutin, minimal sekali sehari. Setelah melahirkan, risiko depresi pada pasien menjadi rendah.

Kedua pasien dan keluarga mengatakan setiap hari mendengarkan bacaan Al-Quran, bahkan sebelum melahirkan pasien mengatakan sudah lebih aktif membaca AlQuran. Menurut keterangan pasien, mereka merasakan kenyamanan saat mendengarkan Al-Quran, lalu mulai tertarik untuk membaca arti dari surat yang didengarkan, dan kedua pasien mengatakan merasa sangat tersentuh dan menjadi lebih mampu menerima kondisinya.

\section{PEMBAHASAN}

Diagnosis adanya kelainan kongenital pada janin merupakan kondisi traumatik bagi orang tua (Aite et al., 2011). Efek psikologis pada orang tua bisa berlangsung lama hingga 
satu tahun pasca persalinan (Hunfeild, 1994 dalam Aite et al., 2011). Oleh karena itu, dibutuhkan intervensi yang dapat meminimalisir terjadinya masalah psikologi bagi orang tua.

Manusia memiliki kecenderungan untuk menikmati harmoni dan ritme yang terkoordinasi dengan baik. Harmoni dan ritme bisa berasal dari suara berupa musik, nyanyian atau lantunan bacaan. Salah satu terapi yang sering digunakan untuk meningkatkan kenyamanan adalah terapi musik. Terapi musik merupakan suatu bentuk distraksi yang dapat meningkatkan kenyamanan (Nilsson, 2008). Banyak penelitian yang menyatakan keefektifan dari terapi musik untuk menurunkan stres, kecemasan dan depresi, salah satunya penelitian yang dilakukan oleh Chang et al (2008) terhadap 236 perempuan hamil.

Kegiatan spiritual yang di dasari pada suara sudah dilakukan sejak ribuan tahun yang lalu (Navidi \& Ghasemi, 2003). Dalam agama Islam, Alquran dianjurkan untuk dibaca dengan perlahan dan diperindah dengan irama, sehingga bacaan Alquran dapat menjadi terapi yang bisa meningkatkan kenyamanan. Suara Alquran adalah suatu jenis musik spritual (Khatoni, 1997). Mendengarkan Alquran dapat meningkatkan kesehatan jiwa dan membawa ketenangan (Mahjoob, Nejati, \& Hosseini, 2016).

Mendengarkan Al-Quran dengan atau tanpa terjemahan terbukti efektif dalam menurunkan stres, kecemasan dan depresi pada ibu hamil (Jabbari, Mirghafourvand, Sehhatie, \& Mohammad-AlizadehCharandabi, 2017). Khadeem et al (2012) telah melaporkan bahwa suara Alquran lebih efektif jika dibandingkan dengan suara musik. Alquran merupakan bagian penting dari agama Islam, karena Alquran diyakini sebagai mukjizat yang turun langsung dari Tuhan. Selain itu, didalam Alquran juga terdapat kisah dan petunjuk bagi umat Islam

Suara bacaan Alquran efektif dalam menurunkan durasi fase aktif saat persalinan (Mirmolaee, 1998). Mendengarkan bacaan Alquran juga terbukti mampu menurunkan intensitas kecemasan selama dan setelah persalinan SC (Mirbagher \&Ranjbar, 2010). Selain memberikan efek positif pada ibu, Alquran juga mampu memberikan efek positif pada bayi. Bayi yang mendengarkan lantunan Alquran menunjukkan penurunan stres juga peningkatan tidur (Polkki, Korhonen, \& Laukkala, 2012).

Selain memberikan pengaruh terhadap psikologis, bacaan Alquran juga memberikan efek positif terhadap fisik. Penelitian yang dilakukan oleh Forouhari et al (2011) menunjukkan efek positif mendengarkan bacaan Alquran terhadap nyeri persalinan. Perempuan yang sedang dalam proses persalinan, saat diperdengarkan bacaan Alquran mengalami penurunan nyeri. Selain itu, suara Alquran juga terbukti memberikan efek yang signifikan terhadap perbaikan saturasi oksigen, pernapasan dan denyut 
Vella Yovinna Tobing', Yati Afiyanti², Tri Budiati3, Terapi Alquran Meminimalkan Risiko Depresi Ibu Hamil Dengan Fetal Anomaly: Penerapan Evidence Based Practice

jantung pada bayi prematur (Keshavarz et al, 2010).

\section{SIMPULAN}

\author{
Pendekatan spiritual dengan \\ mendengarkan bacaan Alquran dapat \\ menurunkan risiko depresi pada ibu. pasien \\ mengatakan merasakan ketenangan setiap kali \\ mendengarkan bacaan Alquran, meskipun saat \\ mendengarkan mereka tidak mengetahui arti \\ dari bacaan tersebut.
}

\section{SARAN}

Pendekatan spiritual, seperti mendengarkan bacaan Alquran, dapat dijadikan salah satu intervensi untuk mengatasi kecemasan, stres, dan mengurangi risiko depresi pada pasien yang beragama Islam.

\section{REFERENSI}

Aite, L., Zaccara, A., Mirante, N., Nahom, A., Trucchi, A., Capolupo, I., \& Bagolan, P. (2011). Antenatal diagnosis of congenital anomaly: a really traumatic experience? Journal of Perinatology, 31, 760-763. http://doi.org/10.1038/jp.2011.22

Chang, M, Y., Caruso, N., Haldeman, S., McNamara, M., Noyes, D., Caroll, D. L. (2001). Effects music therapy on psychological health of women during pregnancy. Journal of Clinical Nursing, 17, 2580-2587

Czeizel, A. E., Dudás, I., Vereczkey, A., \& Bánhidy, F. (2013). Folate Deficiency and Folic Acid Supplementation: The Prevention of Neural-Tube Defects and Congenital Heart Defects, (i), 4760-4775. http://doi.org/10.3390/nu5114760

Forouhari, S., Hanorvaran, R., Maasoumi, R., RObati, M., Zadeh, I. H., \& Setayesh, Y. (2011). Evaluation of auditory effects of the sound of Quran e karim on labor pain.
Journal of Quran and Medicine, 1, 4-18

Hunt, K., France, E., Ziebland, S., Field, K., \& Wyke, S. (2009). "My brain couldn" $t$ move from planning a birth to planning a funeral ': A qualitative study of parents, experiences of decisions after ending a pregnancy for fetal abnormality.

International Journal of Nursing Studies, 46, 1111-1121.

http://doi.org/10.1016/j.ijnurstu.2008.12.0 04

Jabbari, B., Mirghafourvand, M., Sehhatie, F., \& Mohammad-Alizadeh-Charandabi, S. (2017). The Effect of Holly Quran Voice With and Without Translation on Stress, Anxiety and Depression During. Journal Religy Health, 1-11. http://doi.org/10.1007/s10943-017-0417-x Kashyap, N., Pradhan, M., Singh, N., \& Yadav, S. (2015). Early Detection of Fetal Malformation, a Long Distance Yet to Cover! Present Status and Potential of First Trimester Ultrasonography in Detection of Fetal Congenital Malformation in a Developing Country: Experience at a Tertiary Care Centre in India. Journal of Pregnancy, 1-9. http://doi.org/http://dx.doi.org/10.1155/62 3059

Kenkhuis, M. J. A., Bakker, M., Bardi, F., Fontanella, F., Bakker, M. K., FluerkeRozema, J. H., \& Bilardo, C. M. (2018). Effectiveness of 12 - 13-week scan for early diagnosis of fetal congenital anomalies in the cell-free DNA era. Ultrasound Obstet Gynecol, 51, 463-469. http://doi.org/10.1002/uog.17487

Keshavarz, M., Eskandari, N., Jahdi, F., Ashayeri, H., Hosayni, F., \& Kalani, M. (2010). Effect of Quran on physiological responses of premature infants hospitalized in the icu. Semnan Univ Med Sci J, 11(3), 169-177

Khatoni, A. (1997). The effect of reciting the Quran on anxiety of patients hospitalized in the cardiac intensive care unit of selected hospitals in tehran. Msc. thesis

Mahjoob, M., Nejati, J., \& Hosseini, A. (2016). The Effect of Holy Quran Voice on Mental Health. Journal of Religion and Health, 55(1), 38-42. http://doi.org/10.1007/s10943-014-9821-7 
Mills, T. A., Ricklesford, C., Cooke, A., Heazell, A. E. P., Whitworth, M., \& Lavender, T. (2014). Parents' experiences and expectations of care in pregnancy after stillbirth or neonatal death: A metasynthesis. BJOG: An International Journal of Obstetrics and Gynaecology, 121(8), 943-950. http://doi.org/10.1111/1471-0528.12656

Mirbagher, A. N., \& Ranjbar, N. (2010). Effects of recitation of holy Quran an anxiety of women before caesarean section: a randomize clinical trial. Qom University of Med Sciences, 4(1), 15-19

Mirmolaee, T. (1998). Comparison effect of Quran sound and music on the pain intensity in active phase of first stage labor in primipar women hospitalization in two hospital in tehran. Tehran: Tehran University of Medical Sciences

Navidi, A. A., \& Ghasemi S. K. (2003). Comprehensive encyclopedia of medicine: traditional and modern medicene methods. Tehran: Tabib

Nilsson, U. (2008). The anxiety and painreducing effects of music interventions: a systematic review. AORN Journal, 87, 594

Pedersen, M, et al. (2017). Exposure to air pollution and noise from road traffic and risk of congenital anomalies in the danish national birth cohort. Environmental Research, 159, 39-45. https://doi.org/10.1016/j.envres.2017.07.0 31

Polkki, T., Korhonen, A., \& Laukkala, H. (2012). Expectations associated with the use of music in neonatal intensive care: a survey from the viewpoint of parents. Journal Spec Pediatr Nurs, 17(4), 321328

Tucker, J. A. (2016). The experience of the expectant mother following a diagnosis of a fetal anomaly. University of Alabama.

WHO. (2016). Congenital anomalies.

Retrieved from http://www.who.int/mediacentre/factsheet s/fs370/en/ on 26 Desember 2017 